\title{
Verset teen mag: Die pelgrim se reis in drie 'Sondergut' gelykenisse in Lukas 15 en 16
}

\author{
Author: \\ Andries G. van Aarde ${ }^{1}$ \\ Affiliation: \\ ${ }^{1}$ Department of New \\ Testament Studies, University \\ of Pretoria, South Africa \\ Note: \\ This article was initially \\ presented as a paper at the \\ NavNUT Conference 'Mag \\ in die Nuwe Testament', on \\ 16-19 January 2011 at the \\ University of Stellenbosch, \\ Stellenbosch, South Africa.

\section{Correspondence to:} \\ Andries van Aarde \\ Email: \\ andries.vanaarde.up.ac.za \\ Postal address: \\ University of Pretoria, Faculty \\ of Theology, Lynnwood Road, \\ Hatfield 0083, Pretoria, \\ South Africa \\ Dates: \\ Received: 10 Feb. 2011 \\ Accepted: 18 May 2011 \\ Published: 17 Feb. 2012 \\ How to cite this article: \\ Van Aarde, A.G., 2012, \\ 'Verset teen mag: Die pelgrim \\ se reis in drie "Sondergut" \\ gelykenisse in Lukas 15 en \\ 16', HTS Teologiese Studies/ \\ Theolgocial Studies 68(1), \\ Art. \#1032, 11 pages. http:// \\ dx.doi.org/10.4102/hts. \\ v68i1.1032
}

C 2011. The Authors. Licensee: AOSIS OpenJournals. This work is licensed under the Creative Commons Attribution License.
Resistance against power: The pilgrim's journey in three Sondergut parables in Luke 15 and 16. The aim of this essay is to explain the philosophical viewpoints of Michel Foucault concerning the power of knowledge and its consequences when individuals are subjectified into 'docile bodies'. According to this perspective, resistance against power commences when the little stories of individuals are told in opposition to the master narratives of ideologies of power. The essay refers to Steve Biko and Martin Luther King whose stories of resistance against racism as an ideology of power serve as examples. Their examples of resistance are hermeneutically and heuristically applied to the interpretation of the parables in Luke 15 and 16. These parables are peculiar to Luke's theology. The essay exposes the subjectifying of the identities of the 'lost son' and 'father', the 'master' and 'steward', and the 'rich man' and the 'poor man', as these heteronormative categories occur in parabolic stories in Luke 15 and 16. The essay concludes with a vision for Christians today on how to recognise power relationships and how to respond in a non-violent way to the dominant ideologies promoting power.

\section{'n Panopticon?}

In 1975 het my landgenoot en mentor in Semitiese Tale, James Alfred Loader, ' $n$ ThD-proefskrif by die Rijkuniversiteit te Groningen onder promotorskap van A.S. van der Woude, ingedien, getiteld 'Aspekte van menslike mag in die Ou Testament' (Loader 1975). Die totale literêre oeuvres in die Ou Testament, buiten die apokaliptiese dele, is vanuit 'n linguïstiese en literatuurteoretiese perspektief ondersoek. Aan die einde van hierdie komprehensief, struktureel-geörienteerde studie word vooruitsigte op die moontlikheid van soortgelyke ondersoeke na die Nuwe Testament geopen (Loader 1975:356). Heelwat het op hierdie terrein intussen op die gebied van die Nuwe Testamentiese wetenskap verskyn. Werke wat vir my uitstaan, ${ }^{2}$ is dié wat op hermeneutiese wyse die insigte van Max Weber (1864-1920) en Michel Foucault (1926-1984) ${ }^{3}$ in die eksegese verreken het.

Wat die Ou Testament betref, het Loader gefokus op die gebruik van militêre, sosio-ekonomiese en fisiese mag, asook generiese heersersmag, maar ook op wysheid as mag. Vir hom is die 'beoordeling van menslike mag' 'n 'sedelike aangeleentheid'. Loader (1975) verwoord dit soos volg:

Waar menslike mag voorkom, is dit deur God verleen en nie humaan-immanent nie. In werklikheid is God dus die enigste absolute maghebber ... Dit beteken dat mense onder ' $n$ verantwoordelikheid geplaas word wanneer hulle in 'n magsposisie kom. Hierdie verantwoordelikheid het 'n negatiewe en 'n positiewe sy. Die eerste word aangedui deur die feit dat gewelddadige en onregmatige magsontplooiing aan bande gelê en afgewys word. Die tweede kom tot uitdrukking in die eis dat barmhartigheid aan swakkes betoon word. Die besondere aandag vir die swakke - in verbinding met die ontleende kwaliteit van mag - word dikwels gemanifesteer in die omkeer van magsverhoudinge. Hieruit blyk dan dat mag op sigself as iets positiefs gesien word. Die beoordeling van menslike mag is dus in die Ou Testament ' $n$ beoordeling van die aanwending daarvan en die gesindheid daarteenoor. (p. 350)

In hierdie artikel word die motief van 'ommekeer' van magsverhoudings ook as sentraal in die gelykenisse van die Lukaanse Jesus in hoofstukke 15 en 16 uitgewys. Die titel van die artikel vooronderstel egter 'n visie en werkwyse van om die lens van meer abstrak tot meer konkreet in te stel. Die nou reeds bekende metafoor van 'n vliegtuig kan help om te verduidelik (vgl. Esler 2005:58; Van Aarde 2007:1123). In 'n vliegtuig wat op 'n hoogte van 9000 meter vlieg, herken jy

1.Professor James Alfred Loader is tans verbonde aan die Institut für Alttestamentliche Wissenschaft und Biblische Archaeologie, Evangelisch-Theologische Fakultät der Universität Wien, Oostenryk.

2.Kyk onder andere dié van Holmberg (1978), Gunneweg en Schmithals ([1980] 1982), Wink (1984) en Moore (1994). Vir 'n ondersoek na Gunneweg en Schmithals se gebruikmaking van die tradisionele onderskeid tussen potestas en auctoritas, sowel na Holmberg se gebruikmaking van Weber se driedelige onderskeid tussen 'tradisionele', 'charismatiese' en 'legitieme' gesag, kyk Yolanda Dreyer se gebruikmaking

3.Vir die doeleindes van hierdie voordrag is ek wat sekondêre literatuur betref, ten opsigte van Weber deur veral Wolfgang Mommsen (1992) en ten opsigte van Foucault deur Johann Beukes (2009, [2011]) en Scott McLean (1996) gelei. 
alleen groter bakens op die grond soos mere, berge en vlaktes. In die proses om te land verloor jy hierdie groter prentjie en kleiner detail kan dan uitgeken word soos geboue, bome, motors en selfs individuele mense. 'n Meer verantwoorde visie vereis myns insiens perspektiewe op die landskap van beide hoë en lae vlakke.

Dit is daarom verstaanbaar dat sekere sosiaal-wetenskaplik kritiese ondersoeke meer op meesternarratiewe sal fokus en ander op die kleiner narratiewe, en ander op beide. Nie een van die fokuspunte is as sodanig minder wetenskaplik as die ander nie. Wanneer 'n ondersoek, soos die onderhawige, op mag fokus wat die kwessie van stryd teen mag insluit, en die sosiaal-wetenskaplike diskoers bly beperk tot die teoretiese en die abstrakte vlak, sal bevryding ook teoreties beperk bly. So 'n kognitief-emansipatoriese belang het (die vroeëre) Habermas (1971:44-47) sosiale bewusmaking genoem. (Volgens Jürgen Habermas word die voorwaardes vir praxis deur kennis bepaal. ${ }^{4}$ ) Of die lewe van 'n onderdrukte werklik verander het, bly egter 'n ope vraag. Aan die ander kant, sosiale aktivisme sonder 'n teoretiese onderbou, kan dikwels anargie sonder sosiale kohesie tot gevolg hê.

Wat die Suid-Afrikaanse apartheidskonteks van die sewentigerjare betref, het Steve Biko $(1971,1978)$ die rol van die kerk in die samelewing in die stryd teen apartheid erken, hoewel hy self 'n buitekerklike was. Dit geld ook (die latere) Habermas $(2001,2005)$ wat in ons eie tyd ook as niegelowige die rol van die kerk in die stryd teen globalisasie en konsumerisme waardeer. ${ }^{5}$

Met inagneming van sy snydende kritiek teen politieke en kerklike mag, asook die wyse waarop hy as gevangene dood is, is Biko 'n eietydse martelaarsfiguur'. Sy woorde aan dominees in 1971 (in Khoapa 2008:79-80; vgl. Seleoana 2008:21, 40-41) maak van hom 'n 'herinneringsfiguur' na analogie van Martin Luther King, asook na analogie van Lukas se diaken, Stefanus. ${ }^{7}$ Biko se uitspraak in die apartheidsera van die sewentigerjare geld myns insiens net so in die konteks van 'omgekeerde apartheid' in die nuwe na-1994 Suid-Afrika:

In 'n land versadig aan onreg en fanaties gebind aan die praktyk van onderdrukking, onverdraagsaamheid en blatante wreedheid as gevolg van ' $n$ rassistiese geneigdheid; in ' $n$ land waar pa en seun, en tegelyk ma en dogter, dag na dag neuroties 'n totale onvermoë ontwikkel om uit hulle hede na die toekoms te reik, omdat hulle geheel en al deur ellende oorspoel word, kom die

4.Kroger (1985:8) beskryf dit as die 'emancipative praxis of consciousness-raising' In terme van bevrydingsteologie brei hy soos volg uit wanneer hy Habermas (en andere) se bydrae saamvat: 'The prophetic-critical task of conscientization involve a process of enlightenment brought about by a prophetic annunciation of the good news of God's kingdom and a critical denunciation of every dehumanizing socia condition which is contrary to the universal brotherhood, justice, and peace of that kingdom. To announce the gospel is to proclaim the present reality of God's love in the world and promote an awareness of the dignity of all human beings, who together are called to become active subjects of their own history and thus participate in the fulfillment of God's kingdom' (Kroger 1985:17-18).

5.Kyk onder andere Habermas (2001, 2005; vgl. Dreyer \& Pieterse 2010).

6.Cornel du Toit (2008:199-207) se vergelyking tussen Biko en Bonhoeffer is dus van pas.

7.Vir die hermeneutiese kwaliteit van 'herinnering' in die oorlewering van antieke tekste, kyk onder andere Kirk (2005:191-206), en wat die kommunikasie van die gelykenisse van Jesus betref, veral Zimmermann (2008a:87-121). kerk en vul hulle onsekerheid verder aan met 'n aandrang op 'n mea culpa, naamlik dat ons moet bely dat ons die sondaars is. Sondag na Sondag staan die dominees op die kansels met strak gesigte en gooi wavragte blaam op swart mense in die townships, omdat hulle sou steel, by huise inbreek, messteek, moor, ontug pleeg - en só gaan dit aan en aan! Maar niemand probeer eers om hierdie dinge te verstaan deur raakpunte te soek met armoede, werkloosheid, oorbewoning, ongeleerdheid en trekarbeid nie. Dit is so dat niemand veragtelike praktyke volledig kan goed praat nie, maar net so is dit tog nodig om toestande krities te ontleed en darem 'n bietjie dieper te kyk as wat dit op die oppervlak lyk. (outeur se parafrase van Biko, in Khoapa 2008:79-80)

Met hierdie artikel gaan ek as eksegeet - én teoloog én humanis - probeer om dieper te kyk, en die bedoeling is om die vliegtuig op die grond te kry. En hoewel ek vir eers ' $n$ bietjie teoreties vertoef, gaan ek my oog op LukasHandelinge as my landskap hou. Die skrywer van hierdie twee Bybelboeke se Jesus-passie is deur Walter Schmithals (1980:234) beskryf as 'Jesus Weg der exemplarische Weg des Märtyrers' ${ }^{8}$ Lukas se kerk is die ecclesia pressa (vgl. Bovon 2005:546) wat vervolg was deur hoofsaaklik die Romeinse staat, maar ook deur wat kortweg die 'Sinagoge' genoem word. ${ }^{9}$

Lukas het duidelik 'n apologetiese tendens (vgl. onder andere Schmithals 1987:366-386). Dit is soos Rick Strelan (2004) dit stel:

Luke clearly wants his audience to be convinced that this Christian movement is 'of God' ... Issues right from the beginning of the Jesus movement, it would seem, were, Who is this Jesus? Where does he get his authority? Where does he come from? Where do Paul and the apostles get their authority? All seem to be basic questions many of the early Christian writings, including the Gospels, want to answer. So also in Acts, it could be argued that Luke is concerned to prove Gamaliel's hunch right. These men are of God, and so there is no point trying to go against them because by doing so you are only fighting against God (theomachos, 5.39). (p. 28-29)

Met onderdrukking as dekor word die 'Passion Jesu ... als vorbildliches Martyrium geschildert' (Schmithals 1980:12). Dit is ' $n$ 'Passionsgeschichte' wat nie net herinner aan

8.'Das Leiden Jesu hat keine fundamentale Heilsbedeutung. Es geschah (als Martyrium), damit die Schrift erfült wird, und erweist so die Kontinuität von Israe und Wirken Jesu' (Schmithals 1980:12)

9.Schmithals $(1994: 232,237)$ beskryf hierdie toestand tussen die duiwel en die diep blou see so0s volg: 'Die Chyisten sitzen nunmehr rechtlos zwischen die diep blou Stuhhlen und warden soworl von der weiterh in [ Synagoge (een honderd jar later het Tert \& Norelli 2005:339], die vervolging van die kant van die 'Sinagoge' as die fontes persecutionem beskryf) wie von der römischen Obrigkeit bedrängt und verfolgt ... Das lukanischen Doppelwerk blickt auf heftige Christenverfolgungen zurück, die in jüngster Vergangenheit stattgefunden haben und bei denen erst einerseits zu Martyrien, anderseits zum Abfall vom Glauben gekommen ist (Lk 12,4-12; 17:1ff; 21,12-19; Ag 12, 1f; 16,13-40; 22-28) ... Auch solchen apologetischen Gründen streicht Lukas aus seinem Vorlagen auch den Begriff, "Verfolgung", wo dieser auf die römischen Staatsmacht bezogen werden könnte (Lk 6,22par; 8:13par; 18:29fpar), und reserviert inn für das feindliche Verhalten der Juden (Stegemann 1991, 114ff [vgl. Stegemann \& Stegemann 1995:272-305). Damit will Lukas sichtbar machen, daß in den früheren Zeit die römischen Behörden die synagogalen Denunziationen als unberechtigt durchschaut, den Juden kein Gehör geschenkt und die Christen nicht verfolg [worden] t sondern den Juden kein Gehor geschenkt und die Christen nicht verfolg [worden] t, sondern gegen die Antwürfe aus der Synagoge in Schutz genommen haben (Lk 23,14f.22 Ag 16,35ff; 18,12ff; 25,25; 26,30ff u.ö.); ebenso sollten die Römer auch in de Gegenwert des Lukas handeln. (Vir die verskynsel dat die sinagogale owerhed toenemend intensiverend in die post-70 CE as die sondebok vir die onderdrukking gesien is [so verwoord deur onder andere Tertullianus hierbo], kyk onder andere Crossan [1995] [outeur se insetsels in ronde hakies]). 
die verhale van die martelare in die $\mathrm{Ou}$ Testament nie $^{10}$ (Schmithals 1980:12), maar dit weerspieël ook dié van die 'christliche Blutzeuge' in die kerkgeskiedenis wat op soortgelyke wyses onder magsmisbruik gely het (vgl. Schmithals 1980:234).

Soos die reise van pelgrims na Jerusalem wat in aangrypende Ou-Testamentiese psalms in liedvorm bewaar is, is Lukas se 'eksemplariese weg' van die martelaar Jesus en dié van Jesus-volgelinge as 'martelare', 'n reis ná en ván Jerusalem: 'Jerusalem ist die Mitte und Ziel des Wirkens Jesu sowie Ausgangspunkt der Kirche' (Schmithals 1980:120).

Die woord 'pelgrim', met verwysing na die pelgrimsliedere in die Psalmboek, kom van die Latynse peregrinus, 'die in den vreemde verkeer' (De Liagre Böhl \& Gemser 1968:172): 'Telkens toch komt in deze psalmen de herinnering aan doorstane druk en verachting tot uitdrukking en de stemming is die van hoopvol uitzien meer dan van uitbundige jubel' (De Liagre Böhl \& Gemser 1968:172). In die Psalms se pelgrimsliedere verwys die pelgrim metafories na die vreemdeling wat eers in Jerusalem, in die tempel, rus of veiligheid vind, soos byvoorbeeld in Psalm 84:9-13 (vgl. De Liagre Böhl \& Gemser 1968:153).

Dit is daarom opvallend dat wanneer Lukas die geboorte van die kerk in Handelinge 2 met 'n Petrus-toespraak, beskryf hy Psalm 16:9 se:

'my liggaam sal in veiligheid woon' ('af-b'sêri jiškōn labêtah), nie die Hebreeuse weergawe gebruik nie, maar die Septuaginta (LXX Ps

15) se weergawe van 'my liggaam sal in hoop tent opslaan' (he sarx mou kataskēnōsei ep' elpidi). (vgl. Porter 2006:122-123)

Só vervang Lukas in die reismotief die pelgrim se verwagting dat die 'paaie van die lewe' (Hand 2:28/Ps 16:11) by 'n stasie van veiligheid sal arriveer, na die pelgrim se rus wat hoogstens uit hoop bestaan ('rest assured in hope' [Newman \& Nida 1972:51]), dit wil sê 'n nimmereindigende reis waar die 'huis met hande gemaak' (die tempel) met 'n tent (tabernakel) vervang word en vaste veiligheid vervang word met 'n lewe gebou op hoop (vgl. ook Hand 7:14, 47-50; 15:16).

Verskillende terme word deur Lukas vir mense sonder vaste tuiste gebruik. In die Stefanus-rede in Handelinge 7:6 kry ons die woord 'vreemdeling' in die sin van 'buitelandse migrant' (paroikos), ontleen aan die Septuagint. Hiernaas word 'allogtoon' as 'n hapax legomenon in Lukas se Sondergut (17:18) aangetref (vgl. Böhm 1999:28-30). In hierdie kontekas word daar na die 'dankbare Samaritaan' as allogenēs verwys. ${ }^{11}$ Hiëronimus (in Nestle \& Aland 1964:202) vertaal hierdie Griekse word in Latyn met alienigena, en op uitruilbare wyse die Griekse woorde paroikos [bywoner] en paredēmos [volksvreemdeling] met advena [die antoniem van indigena]

10.En die Makkabeër-boeke (kyk onder andere Horsley 2008:57), asook, volgens Van Tilborg \& Counet $(2000: 251,256)$ 'the suffering of some mythological figures that was willed by God', veral Dionysos en Heracles.

11.Die uitdrukking 'vreemdeling-as-buitelander' (xenos) wat ons in die Matteus Sondergut-gelykenis $(25: 35,38,43,44)$ aantref, kom nie in Lukas-Handelinge voor nie. Hierdie term word saam met parepidēmos, 'n 'tydelike inwoner', in Hebreërs 11:13 gebruik om na die Abraham-kring in Palestina te verwys. of peregrinus (vgl. 1 Pet 1:1 met 1 Pet 2:11). Die uitdrukking (in akkusatief) advenam gruem word deur Horatius gebruik om na 'n 'kraanvoël in migrerende verbyvlug' te verwys (kyk Quintus Horatius Flaccus, [1823], Clevis Horatiana, 35; vgl. Cassell [in Simpson] 1966:220).

Dit is egter die woord peregrinus wat etimologies aanleiding gegee het vir die woord pelgrim (kyk die Odhams Dictionary [in Smith \& O'Loughlin s.a.:794]) in oud-Engels as 'pelegrim'. In Augustinus (Civitas Dei 18.51) word die Latyn peregrinus of peregrina in kontekste gebruik om op allegoriserende wyse na analogie van die Bybelse figure Abel, Abraham én Jesus - na die kerk te verwys as 'pelgrims' wat bloot tydelik in saeculo vertoef en as't ware aan die verby loop (peregrinari) is. Hoewel daar in Ovidius (Metamorphoses, Met. Lib. 15) 'n positiewe gebruik van hierdie woord in terme van vreemde lieflinge ('foreign sweethearts') voorkom, is Titus Livius (Ab Urbe Condita, 26) se pejoratiewe verwysing na terreur veroorsaak deur vreemde vyande ('foreign enemies') egter die meer algemene gebruik (kyk Simpson 1966:435). Dit word deur Augustinus se gebruik van die term peregrina vir die kerk as 'stad van God' bevestig. Volgens Hans van Oort (2011) is 'een wezenlijk aspect' van die uitdrukking 'stad van God' die 'nadruk op de vreemdelingschap'. Hy verwys self soos volg hierna: 'Wie De stad van God opslaat, wordt getroffen door dit aspect (zie de opsomming van alle teksten in ciu in Van Oort 1991:131-142).'

In hierdie sin verskil die semantiese gebruik van die twee woorde 'pelgrim' en 'allogtoon' nie veel van mekaar nie. Buiten die Septuagint kom allogenès net nog in die apartheidinskripsie in die Jerusalemse tempel voor wat nierasegte Israeliete met die dood dreig as hulle die voorhof van die Israeliete sou durf betree ${ }^{12}$ (vgl. Büchsel 1985, TDNT, I, pp. 264-267). Dit kom dus nie as verrassing dat hierdie begrippe in die Suid-Afrikaanse teologie in die stryd teen apartheid deur eksegete bespreek is nie, byvoorbeeld deur myself in terme van Matteus 28:16-20, en met verwysing na my voorganger, professor Albert S. Geyser, se eksegese van Handelinge 2 (kyk Van Aarde 1986:77-93, 1992:159-182).

Insgelyks wil hierdie bydrae oor die begrip mag - spesifiek gesien vanuit Lukas se Sondergut-perspektief - nie die kwessie van óf rassisme en seksisme óf liberalisme óf vrees vermy nie. Inteendeel, ek beskou hierdie ideologieë as die meesternarratiewe in terme waarvan ek drie gelykenisse in Lukas 15 en 16 bespreek.

Daar is 'n rede waarom ek die opskrif 'Panopticon' vir die inleiding tot hierdie artikel gebruik. In 1785 het die Engelse filosoof en sosiale teoretikus, Jeremy Bentham, die argitektoniese vorm van 'n tronk ontwerp waar bewaarders 'n volledige (pan-) opsig (-opticon) oor gevangenes het, hulle deurentyd bewus is dat opsig oor hulle uitgeoefen word, maar die institusionele bron van die kontrole bly onsigbaar (Bentham 1995:29-95; kyk die internetverwysing

12.Josephus, De bello Judaico 6.125; 5.194; Antiquitates Judaica 15.417 (kyk Niese, B 1955, Flavii losephi opera, Weidman, Berlin), ignoreer hierdie inligting, waarskynlik om nie sy Griekssprekende lesers te vervreem nie. 
deur Wikimedia Foundation 2010, asook Beukes 2011) Die argitek, Silke B. Lang (2004), het in sy PhD-proefskrif hierna verwys as die 'sentiment of an invisible omniscience'. Bentham (1995:29-95) self het dit beskryf as 'a new mode of obtaining power of mind over mind, in a quantity hitherto without example'. Michel Foucault (1982:778) het dit as 'n breë metafoor gebruik ${ }^{13}$ om na die Eurosentriese samelewing te verwys wat ongemerk heteronormatief mense se lewens beheer: mal versus normaal, siek versus gesond, goeie mense (cowboys) versus slegte mense (crooks), homosekusueel versus heteroseksueel, ensovoorts.

Foucault se stryd teen mag wil die diskoers blootlê dat 'n oorwinning teen onderdrukking nie in die eerste plek daaruit bestaan om die panopticon as struktuur op revolusionêre wyse af te breek nie. Die stryd begin by die bewussyn van die klein narratiewe van ('n) mens(e) - iemand met 'n naam - wat bevry word van viktimiserende verdingliking ('rë̈fikasie') wat hulle aangedoen word met die instrumentele hulp van heteronormatiewe meesternarratiewe - of dit oor gesondheid gaan of oor patologisering of oor rassisme of apartheid of seksualiteit.

Gender, ekonomiese, politieke, swart of wit bewussyn diskoerse van ideologie-kritiek het ' $n$ plek, ook in teologiese hermeneutiek en eksegese, maar dit is die heuristiese dinamiek van die hermeneutiek van 'n klein diaforiese narratief, soos 'n gelykenis van Jesus, wat myns insiens die krag het om 'n verskil in die lewe van enkelinge teweeg te bring.

Die moontlikheid dat die woord 'pelgrim' doodgewoon op die lewensverhaal van 'n enkeling betrekking kan hê, het my in my oortuiging gesterk om Foucault se insig in mag op Jesus se gelykenisse toe te pas. Dit is waarom Lukas se Sondergut, dit wil sê eiendomlike gelykenisse van Jesus spesifiek van toepassing kan wees.

In Lukas 15 en 16 word verhale oor mense vertel wat op grond van die samelewing se norme stereotipiese 'identiteite' deur middel van pejoratiewe stigmatisering gekry het: die 'afvallige jonger kind' wat nie soos sy ouer broer voorbeeldig is nie, en die pa wat nie aan sosiale verwagtings voldoen nie; die bestuurder wat geld mors, en die baas wat nie straf soos die strafreg bepaal nie; die arm mens wat dit slegter het as honde en volksvreemdelinge (die term 'hond' is die stigma waarmee die vreemdeling ontmenslik is). Hierdie mense sondaarskinders, onverantwoordelike base en arbeiders, armlastiges - is almal mense wat Johann Beukes ([2011]), na aanleiding van Foucault, beskryf as 'geaffekteerde, genormaliseerde en diep versteurde subjekte'. Hulle verhale kom in die Christene se Bybel voor en dit is spesifiek Lukaans, dit wil sê Sondergut. Sy eiendomlike materiaal.

Die eiendomlike veronderstel individualisering bevry van veralgemening. Lukas se verhale van die lewe van beide Jesus en die kerk is dikwels vertellings oor 'pelgrimerende'

13.Volgens ook Lockhart (2008:54) se novelle waar die protagonis hiervan slagoffer in Foucault se sin van die woord is. martelaars wat slagoffers was van politieke, religieuse en kulturele empires. Lukas knoop egter nie die stryd teen mag aan om die Empire tromp op te pak nie. In die beeld van Karl Ludwig Schmidt (1919) van jare terug, weef Lukas die een kortverhaal by die ander in, soos krale wat aan ' $n$ lyntjie geryg word, totdat sy eerste en sy tweede verhaal as twee opeenvolgende pelgrimsreise, eers dié van Jesus en toe dié van die volgelinge van Jesus, ná en ván Jerusalem, één pelgrimerende reisverhaal ${ }^{14}$ vorm waarvan ek as leser en eksegeet saam met voorgangers deel geword het. ${ }^{15}$

Daarom, meer nog, my eietydse twee voorbeeldvertellings (gevallestudies) is 'pelgrims' wat albei proponente was, in Foucault se sin van die woord, wie se lewe en sterwe van só 'n stryd teen mag getuig. Hulle is Martin Luther King en Steve Biko. Oor Biko het ek reeds iets gesê. Nou kan ek die verband tussen Biko en King lê. Beide, bewus daarvan dat die meesternarratief nie uit die oog verloor mag word nie, was nie sonder suspisie ten opsigte van die versluierde, skadeberokkende mag agter ideologieë nie, of dit sosialistiese liberalisme en 'Bantustan-rassisme' van Wit mense is of die geïnternaliseerde homofobie van Swart mense (vgl. Pityana 2008:6, 11). In sy outobiografie, 'Pilgrimage to nonviolence', het Martin Luther King ([1958] 1986:35-40) self vertel hoe ook teologiese liberalisme, net soos geweld, nie vir hom die oplossing in sy stryd vir menswaardigheid kon wees nie. Dit bly merkwaardig dat King ([1958] 1986:40), soos die evangelis Lukas, bly vashou het aan die ideaal dat daar wel 'n goedgeaarde mag ('benign power') kan bestaan. ${ }^{16}$

Lukas is nie net die evangelis wat een van twee kwaaddoeners (kakourgoi - Luk 23:32,39) wat saam aan die kruis hang, vir Jesus laat vra om hom in herinnering te roep wanneer Jesus in sy koninkryk kom (wat dit ook al mag beteken!), en Jesus wat antwoord (Luk 23:43): 'Amen, ek sê vir jou, vandag sal jy saam met my in die paradys wees (wat óók dit mag beteken). Lukas is ook die één wat Jesus aan die einde van sy pelgrimsreis na Jerusalem laat siteer uit Habakuk 2:11 dat as sy dissipels begin swyg om nie meer te vertel van hom wat kom in die naam van God en dat daar vrede by die heerlikheid van God te vind is nie (Ps 118:26; Luk 23:38), die klippe dit sal uitroep (Luk 23:40)!

Hierdie artikel sou daarby kon baat indien daar ruimte was om meer oor King en Biko te vertel. Hulle 'klein narratiewe' het baie vir ons te leer. Maar ruimte laat nie toe nie. Die

14. Hoewel die literêre motief van Jesus se reis na Jerusalem van Markus as tradisie afkomstig is (Mark 9:30; 10:1, 17, 32 e.v., 46; 11:1, 11), was K.L. Scmidt (1919:247249) die eerste eksegeet wat ingesien het dat die beweging op die reis na Jerusalem 'n Lukaanse skepping is deurdat dit in 'n raamwerk van perikope geplaas is (Luk 9:51; 13:22, 33; 17:11; 18:35; 19:1, 11) (vgl. o.a. Robinson 1960:24-25).

15.Wat die rol van die leser in betekenistoekenning betref, veral ten opsigte van Jesus se gelykenisse, stel Charles Hedrick (2004:94-95): 'The modern reader's own personal reaction to the story is just one response among many. A reader's response should never be construed as the ultimate meaning of the parable, for there have been many responses to the parable, and there will be others in the future. The parable's "voice" is how it resonates in its own way for each reader.

16.'True, I have always believed in the personality of God. But in the past years the idea of a personal God was little more than a metaphysical category which I found theologically and philosophically satisfying. Now it is a living reality that has been theologically and philosophically satisfying. Now it is a living reality that has been validated in the experiences of everyday life. Perhaps the suffering, frustration and agonizing moments which I have had to undergo occasionally as a result of $\mathrm{my}$ nvolvement in a difficult struggle have drawn me closer to God ... In the midst of outer dangers I have felt an inner calm and known resources of strength that only God could give. In many instances I have felt the power of God, transforming the fatigue of despair into the buoyancy of hope' (Martin Luther King [1958] 1991:40). 
artikel bestaan dus eintlik uit net twee dele. Eerstens vertel ek hoe ek Foucault se stryd teen mag verstaan. Tweedens, lees ek drie Sondergut-gelykenisse in Lukas 15 en 16 as 'n ineengerygde perikopereeks in terme van ' $n$ stryd teen mag in die lig van Foucault se verstaan. As afsluiting kom ek terug op die appèl wat 'ommekeer' as motief in hierdie gelykenisse myns insiens kan veronderstel.

\section{Die stryd teen mag}

Michel Foucault help ons om die aard van patrone van mag in historiese en kontemporêre samelewings beter te begryp. In kort kom dit daarop neer dat mag mense verdinglik (reifiseer) deur hulle te 'objektiveer' - volgens Foucault, subjektiveer, dit wil sê tot 'onderdaan' maak. In sy werke toon Foucault die verskeidenheid van wyses aan waarop mense deur kultuur tot objekte gemaak word (vgl. onder andere Foucault 1982:777). 'n Mens word 'n objek in verhouding tot iemand anders omdat jy (1) deur iemand anders gekontroleer en afhanklik van die daardie persoon gemaak word, sodat (2) jy as 'objek' gebind word aan wat vir jou en namens jou as jóú identiteit gereken word - dit gebeur terwyl jy hiervan bewus is op grond van selfkennis van jou kondisie (Foucault 1982:781). Wat aan't gebeur is, is om ingebed te wees in patrone van lewe waaraan jy as objek uitgelewer is. Ander is dus die arbiters oor jou denke en praktyke. Die ander wat dit aan jou doen, beskou jou toegekende identiteit as integraal tot jou menswees (being), dit wil sê 'n taken-for-granted objekwees. Hierdie proses van 'objektivering' is die konteks van hedendaagse Westerse regeerwyse. Dit manifesteer nie opsigtelik as regering deur middel van geweld of koërsiewe mag wat sigbaar is in eksplisiete taktiek van koërsiewe handelinge nie. Dit manifesteer wel in die daarstel en konstituering van en die dissiplinering deur regering, wat daaruit bestaan dat jy jouself deur hierdie proses laat regeer.

Mense word op grond van vermeende objektiewe kenmerke gekategoriseer. Dit geskied byvoorbeeld in instellings soos die psigiatrie, geneeskunde en strafreg. Mense word op heteronormatiewe wyse getipeer as 'mal of normaal', 'gesond of siek', 'sleg' of 'goed' (kyk Foucault 1982:778, 1986:229-242). Die uitvra oor mense se ervaring, veral oor hulle seksualiteit, word 'n ervaring wat geïnternaliseer word en lei daartoe dat mense hulleself in terme van toegekende identiteite aanvaar, daarby berus maar heimlik daarteen stry. $\mathrm{Al}$ hierdie tipe uitvrae is prosesse van publiek maak van wat van nature mense se reg op privaatheid is. Op grond van die uitvrae word daar op wyses van sogenaamde berading besluit, terwyl eintlik beoordeling plaasvind.

Deur te fokus op hierdie tipe uitvrae wil Foucault dat ons anders sal begin dink oor die begrippe 'onderdrukking', 'mag' en 'weerstand'. Dit bied riglyne tot sosiale optrede (agency) in 'n postmoderne wêreld. Wat 'onderdrukking' betref, lei hierdie riglyne tot die vraag: Wat is die verskeidenheid van regulasies van mag wat die patrone van onderdrukking handhaaf of teenstaan? Sodoende word sistemiese onderdrukking op twee maniere uitgelig. Onderdrukking vind nie plaas omdat daar van bo-af mag uitgeoefen word nie. 'n Sisteem van onderdrukking kom tot stand deur ' $n$ variasie van praktyke en verhoudings - en dit geld vir alle mense. Volgens Foucault (1978:88) hoef ons dus nie die koning se kop af te kap soos die revolusionêre tydens die Franse Revolusie gedink het nie. Wanneer dit kom by 'n analise van mag, behoort ons eerder raak te sien hoe mense in hulle alledaagse denke en praktyke ingebind is (en dit ook ondersteun!) in patrone van magsrelasies wat aan onderdrukking 'n sistemiese vorm gee.

Foucault (1986:232) daag ons uit om ons eie betrokkenheid in onderdrukking te erken. Daar is tye en plekke waar onderdrukking gekonsentreerd voorkom en handelinge vertoon wat ook patrone elders het en daarom ook meer langdurige gevolge het. Sekere tye gee aanleiding tot spesifieke toestande van politieke dominansie, ekonomiese eksploitasie en reïfikasie (Foucault 1982:781). In feodale samelewings sal sosiale geweld ineen gevleg wees met kategorieë soos etnisiteit, religie, kultuurgroep (kaste of volk). Gedurende die laaste twee eeue van industrialisasie het arbeiders 'n stryd gevoer teen eksploitasie waardeur mense ten koste van ander hulleself verryk het. Tog behoort ons hedendaagse stryd volgens Foucault nie in die eerste plek teen polities-ekonomiese dominansie te wees nie. Ons behoort eerder oor individue begaan te wees as oor mag as universele verskynsel. Ons behoort bewus te raak van die ekstreme uitwerking van mag waar dit in 'lokale vorme en instellings' voorkom (Foucault 1986:232).

Objektivering is ons tyd se vernaamste vorm van onderdrukking. Te geredelik aanvaar ons dit as 'n algemene toestand dat individualiteit die mees natuurlike gegewendheid van menswees is. Daarom behoort ons Eurosentrisme gedurig te dekonstrueer as dit as normatiewe patroon van lewe vir almal elders voorgehou word. Dit is egter nie maklik om die proses van objektivering raak te sien nie. Onderdrukking is dus nie die gevolg van 'n hiërargiese komplot op die patroon van die panopticon nie. Mag is nie iets wat geheel-en-al in die hande van één persoon wat alléén dit op totalitêre wyse uitoefen nie. Dit is eerder soos 'n tuimeldroër waarin ons almal vasgevang is - en dit geld hulle wat mag uitoefen én hulle oor wie mag uitgeoefen word.

Daarom is mag die uitkoms van 'n verskeidenheid en uiteenlopende praktyke. Ook die mees goedbedoelde handeling om te bemagtig kan mense vasbind. Mense kan só volkome geïdentifiseer word met sekere van hulle kenmerke en aktwiteite. Iemand word vereenselwig met wat van boaf aan hom of haar toegeskryf word. So byvoorbeeld kan 'n vriend wat met kanker gediagnoseer is, vir jou slegs 'n 'kankerlyer' wees. Mense word so hulle volle menswees ontsê en bloot 'n objek gemaak. So kan 'n mens jou vaskyk in iemand se seksuele oriëntasie en hy vir jou slegs 'n 'gay' en sy 'n 'lesbiër' word.

Die mens as individu is wesenlik onverskillig en ontken die moontlikheid om self ' $n$ maghebber te wees, of dat jy deur 'n daad van mag geaffekteer word - en wanneer dit jou negatief tref, oorweldig die gebeure jou; wat jou inderdaad 
ook kan breek (Foucault 1986:234). Bemagtiging behoort alternatiewe, nie-onderdrukkende relasies vir mense daar te stel. Deur die proses van reïfikasie ernstig op te neem, sal ons die inbinding van individue deur kategorisering en die afforsering van sogenaamde norme herken. Dit vra om ook van ander te verwag om hulleself as sodanig raak te sien (Foucault 1982:781). Mag is orals, nie omdat dit alle mense raak nie, maar omdat dit van orals kom (Foucault 1978:3). Mag is 'n proses en is deel van sosiale verhoudings (Foucault 1982:786).

Sosiale verantwoordelikheid is die wagwoord, benewens realisme en sensitiwiteit (vgl. McLean 1996:18). Ons behoort nuwe vorme van identiteitvorming te bevorder deurdat ons weier om ons 'subjektivering' te aanvaar wat oor eeue heen ons daarin laat sosialiseer het (Foucault 1982:785). Daar is heelwat voorbeelde van weerstand bied, soos die opposisie teen mag van mans oor vroue, van psigiaters oor geestelik siekes, van dokters oor pasiënte of van administratiewe burokrate oor mense se lewenswyse (Foucault 1982:780). Die doel van die stryd is dat individue sal uitstyg bo konformisme. Dit is egter nie genoeg om slegs met demonstrasie politieke en ekonomiese eksploitasie teë te gaan nie. Ons kan nie maar stilbly oor hoe mense gewillig deelneem aan onderdrukkende vorme van sosiale relasies nie. Daarom behoort ons ons tradisionele begrip van mag te hersien (Foucault 1978:4).

Hierbo het ons reeds opgemerk dat beide Martin Luther King en Steve Biko nie sondermeer aan liberalisme ' $n$ 'messiaanse' kwaliteit verleen het nie. Hierdie selfde kritiese houding kry ons by Michel Foucault. Met skerp insig toon hy aan dat in die liberale demokrasie ${ }^{17}$ 'oortreders' op minder brutale wyse gestraf word, sodat hulle eintlik meer effektief gestraf kan word (Foucault [1975] 1995:27). Ook die sogenaamde selfhervormende kerk is hieraan skuldig. Wat plaasgevind het, is dat dissipline ongemerk verskuif het vanaf 'n uiterlike en 'harde' gesag na kontrole wat mense se liggame en ook hulle 'hart' (in 'ou' Platoniese digotomie: die mens se 'siel') beheer - en die hartseer van hierdie subtiele onderdrukking is dat mense dit as 'normaal' aanvaar en daarby berus! Foucault ([1975] 1995:173) beskryf hierdie proses as 'polisiëring'.

Die eksplisiete en gewelddadige weerstand teen onderdrukking wat in die Suid-Afrikaanse konteks van apartheid tot die regering se regulering van 'n sogenaamde noodtoestand gedurende die tagtigerjare gelei het, is tipies van 'n 'polisiestaat'. Hoewel 'polisiëring' 'n moderne verskynsel is, was dit nie onbekend in die antieke wêreld nie. Antieke owerhede het dikwels met gewelddadige onderdrukking op vermeende of werklike oproerigheid van onderdane reageer ${ }^{18}$. Foucault se insig in die 'normalisering' en berusting van 'polisiëring' deur onderdane bied 'n teoretiese riglyn vir die praktyk van nie-geweld as antwoord op onderdrukking wat selfs gewelddadig kan wees.

Panoptiek as magsuitoefening is die ideologiese onderbou

17.Liberale demokrasieë soos onder meer die VSA en die VK, is voorbeelde van moderne panoptiese magsuitoefening. Beukes (2009:5-6) wys op hierdie 'wêreldmoondhede' se beleid ten opsigte van Iran in die laat-sewentigerjare en bespreek Foucault se kitiek op die 'subjetivering' van die sogenaamde 'Orientale'.

18.Kyk onder meer Philo [1962], Legatio ad Gaium, 38, 302 (vgl. Seland 1995:ix). van onderdane se onbevraagtekende aanvaarding van polisiëring. Juis as gevolg van die alomteenwoordigheid van onsigbare magsuitoefening word polisiëring as normaal en nodig gereken (vgl. Foucault [1975] 1995:183). Onderdane konformeer dus met magskontrole! Hulle word 'docile bodies' (Foucault [1975] 1995:202-203). Die resultaat is: 'observe, control, normalise, and examination' (Foucault 1995:173). Beukes $(2009: 5,6)$ beskryf hierdie hiërargiese proses as die OCNE-beginsel. Die laaste stap in die proses, te wete 'examination' behels dat konformiste beloon word en nie-konformiste (diegene wat onderdrukking teëstaan) gestraf word. Hierdie straf is meer intens omdat dit ' $n$ mens so kan reïfiseer deurdat onderdrukking as normaal aanvaar word. Beukes beskryf die mens wat só 'n 'docile body' geword het, as 'n 'versteurde subjek' (vgl. Foucault 1972:4).

Waar Foucault aanvanklik nie gemeen het dat 'n mens die vermoë het om weerstand te bied teen hierdie panoptiese magsbeheer nie, het hy aan die einde van die sewentigerjare met die skryf van sy triologie History of sexuality wel met 'n antwoord vorendag gekom. Effektiewe weerstand teen mag het hy as 'local resistance' begin beskryf, die sogenoemde 'partikuliere verset'. Omdat mag orals is, ingebed in elke mikro-aspek van die samelewing, behoort weerstand vanuit die individu self te kom. Die analise en optekening ('argeologie' en 'genealogie') van die 'klein narratief' is dus meer doeltreffend as die beskrywing van die 'meesternarratief'. Eers as die mens as individu haar of sy vryheid opeis, kan weerstand gebied word. Paradoksaal gesien, word alleen vry mense onderdruk. Die verdrukte is reeds aan kettings gebind, soos ' $n$ slaaf wat nie weerstand kan bied nie! Beukes ([2011]) beskryf Foucault ([1975] 1995:223) se proses van weerstand bied soos volg: analiseer en gee 'n verdere uitbouing aan jou analise deur raak te sien en op te teken dat daar ' $n$ verhouding tussen mag en die aantasting van jou vryheid bestaan. Die erns maak van weerstand bied behoort integraal tot jou bestaan as sosiale wese te wees en dit behoort ' $n$ konstante taak in jou lewe te wees. ${ }^{19}$

Waarop dit myns insiens neerkom is: neem jou vryheid terug wat sogenaamd aan jou gegee is toe aan jou ' $n$ identeit gegee is wat jou eintlik slaaf gemaak het. ${ }^{20}$ Bied weerstand teen etikettering en stigmatisering. Maak beswaar teen die aanspraak dat die samelewing van jou verwag om jou toestand as 'normaal' te ag, terwyl jy weet dat hierdie toestand jou liggaam en siel skade berokken. Wees ook suspisieus wanneer aan jou verkondig word dat God, Bybel of kerk van jou aanvaarding eis dat jy sogenaamd is wat jy is!

Hoe lees ons Jesus se subversiewe houding? Uiteraard behoort ons dit te lees in terme van sý konteks. Of ons kan dit lees in terme van die kontekste van die skrywers van die evangelies wat vir Jesus geïnterpreteer het. Hoe doen ons dit teen die agtergrond van die insigte van Foucault? Ons ontbloot verdingliking. Ons maak soos Steve Biko en

19.Foucault ([1975] 1995:221-222) stel dit soos volg: 'At the very heart of the power relationship and constantly provoking it, are the recalcitrance of the will and the intransigence of freedom.

20.Met behulp van die begrippe 'argeologie' en 'genealogie' het Foucault (1977:145146) identiteitvorming in die diskoerse van mag in die menslike samelewing analiseer en die uitbouing daarvan in relasies van mag ontbloot (kyk Beukes [2011]). 
Martin Luter King. Ons rig ons weerstand nie as sodanig teen abstrakte ideologiese meesternarratiewe nie. Ons erken die waarde van klein narratiewe. Ons fokus op lewensverhale van individue en merk op hoe hulle van hulle kategorisering en patologisering bevry word.

Dit is waarom ons op die Lukaanse verhaal van die sogenaamde 'oneerlike bestuurder' as voorbeeldstudie fokus. Ons sien die ommekeer van etikettering raak. Ons merk op hoe barmhartigheid op 'n vreemde wyse as deug verkondig word. Ons vra na die kriteria hoe om self agency te neem.

\section{Die 'ommekeer' in Lukas 15 en 16}

Daar is nie 'n rede waarom spesifiek Lukas 15 en 16 uit die Lukaanse reisverhaal gekies is nie. Verskeie ander motiewe in hierdie verhaal wat by Lukas 9:51 begin en volgens my by Lukas 19:44(46) eindig, ${ }^{21}$ het die motief van 'ommekeer van mag' in die oog. Die drie Die eiendomlike-gelykenisse wat ek aan die orde stel, is dié van die 'verlore seun', dié van die 'skelm bestuurder' en dié van die 'arm Lasarus'. Indien my leser, lesend en reisend, met die interpretasie gaan saamstem, sal die insig in die ommekeer van mag ons kan bring om wéér - nou as't ware vir die eerste keer - die eerste van hierdie drie gelykenisse te lees as die klein narratief van die 'belydende Afrikaner', die tweede as dié van die 'bekeerde dominee' en die derde as dié van die 'barmhartige daklose'. Die verhaal van die 'verlore seun' bind ek dus eerder met perikope vorentoe in die plot as met perikope agtertoe. Die 'verlore skaap' en die 'verlore rand' skets vir my die dekor waarteen ek die stories oor die 'Afrikaner', die 'dominee' en die 'daklose' kan lees.

Hierdie dekor se horison reik verder terug tot waar die reisverhaal aan die een kant by Lukas 9:51 begin en aan die ander kant by Lukas 19:44, 46 eindig, met die appèl om dinamies self, eerder as dat die 'klippe van die geruïneerde stad van God wat ' $n$ murasie geword het', ${ }^{22}$ uitroep dat God se mag of koninkryk in en deur Jesus in kontinuum met ander martelare herkenbaar is.

Michael Wolter (2008:364) beskryf Lukas 9:51-18:34 as 'Der Weg nach Jerusalem' en Lukas 18:35-19:46 as 'Das Ende der Wanderung' (Wolter 2008:606). Hierdie indeling ondersteun my eksegese. Hoofstukke 15 en 16 is die 'pêrels' (kyk my verwysing na K.L. Schmidt hierbo) in die verhaallyn van die pelgrimsreis ineengeryg. Wolter (2008:514) se opskrif vir Lukas 14:25-18:35 as 'iewers op weg' ('Irgendwo unterwegs') is treffend. In hierdie passasie word een na die ander verhaal vertel dat wie hulleself verhoog, sal verneder word. Van die perikope is dié oor die dissipels wat die koste van dissipelskap nie werklik bereken het nie (Lukas 14:25-33),

21.Contra Du Plessis (1995a:106, 195) wat die reisverhaal by Lukas 19:28 laat eindig.

22.Vir die profeet Habakuk en die evangelis Lukas was die 'stad van God' ' $n$ verwysing na Jerusalem, en vir Augustinus en vir myself ' $n$ verwysing na die kerk as instituut. asook 'n aanklag teen die powers that be ${ }^{23}$ wat die profete en hulle gewete doodmaak (Lukas 13:31-35). Hierdie appèl is deur Lukas 13:1-9 ingelei, 'n perikoop wat Wolter (2008:474), weer eens treffend, as die 'Letzer Aufruf zur Umkehr' beskryf. Hoofstuk 15 word breedweg getitel as 'Umkehr von Zöllnern und Sündern', hoofstuk 16 as 'Richtigen Umgang mit Geld und Bezitz', hoofstuk 17 as 'Rede an die Jünger' en hoofstuk 18 as 'Pharisäer und Zöllner'.

Wat hoofstuk 16 betref, fokus ek op een van Jesus se moeilik verstaanbare gelykenisse ${ }^{24}$ (vgl. Snodgrass 2008:401), naamlik sy gelykenis waar die sogenaamde 'skelm' finansiële bestuurder geprys word. In aansluiting by Krämer (1972:27) praat Ireland (1992:6) van die 'oerwoud van verklarings' ('das Urwaldes der Erklärungen'). Ek vind die ontknoping in Lukas 16:10 wat ek soos volg vertaal:

Die mens wat lojaal ten opsigte van die geringste is, is óók lojaal ten opsigte van baie; en die mens wat onregverdig teenoor die geringste is, is óók onregverdig in baie dinge. [Outeur se eie vertaling]

Dit is ' $n$ gelykenis wat vir baie Bybellesers een van die mees raaiselagtige - indien nie die moeilikste nie - gelykenisse is wat Jesus volgens oorlewering ooit vertel het. G'n wonder nie dat daar eksegete is wat meen dat die beste manier waarmee die woord 'gelykenis' in moderne tale vertaal kan word, die woord 'raaisel' is (kyk Rhoads \& Michie 1982:55-58; vgl. die uitdrukking in die titel van Krämer 1972 se boek: Das Rätzel der Parabel vom ungerechten Verwalter).

Jesus se gelykenisse is beeldspraak waarmee hy die wêreld van God met behulp van voorbeelde uit die daaglikse lewe van werklik materieel arm kleinboere verduidelik. Kenneth Bailey ([1976] 1996) se beskrywing van die gelykenisse in Lukas 15 en 16 as 'through peasant eyes' het besondere trefkrag. Kleinboere ('peasants') was die ongeveer 85\% massas wat uitgebuit was deur die $5 \%$ ryk 'estate' eienaars wat ver weg in die stede gewoon het (vgl. Stegemann \& Stegemann 1995:17-94). Daar het 'n diep apartheid tussen die elite en die kleinboere bestaan. Die twee groepe was bemiddel deur ongeveer $10 \%$ ander wat voordeel daaruit gekry het op gebiede soos finansies, politiek en sosioreligieuse status. Hierdie bemiddelaars ('retainers') was burokrate, skrifgeleerdes ('scribes'), soldate, priesters en handelaars. $\mathrm{Na}$ aanleiding van die insigte van Douglas Oakman (1991:173) meen Kloppenborg en Callon (2010:34) dat Lukas se baie verwysings na mense van 'lae klas op die platteland', die evangelis se vertellersperspektief konstitueer as dié van iemand onder die 'educated sub-elites'.

Die woord 'bestuurder' wat in die gelykenis in Lukas 16:1-13 voorkom, beteken eintlik 'huisheer'. Die Grieks is oikonomos

23.Volgens forum.wordreference.com is die uitdrukking 'powers that be' ' $n$ "biblical allusion that has become a stock phrase: Let every soul be subject unto the higher powers. For there is no power but of God: the powers that be are ordained of God (Romans 1,3$)$. It is generally used just to mean "those in control" of a particular situation.' En volgens www.english-for-students.com/The-Powers.html het die situation. En volgens www.english-for-students.com/The-Powers.html het die frase die eerste keer in die vertaling van Romeine 13 in die Tyndale's Bible (1526) verskyn: 'Let every soul be subject unto the higher powers. For there is no powe but of God: The powers that be are ordained of God.' Dit beteken: 'The established government or authority' (vgl. Phrase Dictionary - Meanings and Origins, www. phrases.org.uk).

24.Wat die 'Rätselhaftigkeit' van Jesus se gelykenisse betref, oordeel Ruben Zimmermann (2008b:5): 'Unverständlichkeit ist konstitutiver Teil der Parabelrede.' 
en die Latyn is dominus (afgelei van domus, wat 'huis' beteken). Die Latyn het tot ons woord 'dominee' gelei en die Grieks tot ons woord 'ekonoom'.

Hoe ook al sy, in Jesus se storie gaan dit oor iemand wat verantwoordelik is om ' $n$ maghebber se belange by mense op die voetsoolvlak te bemiddel. Wat die gangbare in daardie tyd was, was dat hierdie belang aanleiding sal gee tot groter voordeel enersyds vir diegene wat het en andersyds groter nadeel vir diegene wat nie het nie. In Jesus se gelykenis word hierdie konvensie gedekonstrueer.

Die vraag is: wat wil die Lukaanse Jesus deur middel van hierdie verhaal vertel oor God se verhouding met mense?

God se verhouding met mense word deur Jesus die 'koninkryk van God' genoem. Die kleinboere van daardie tyd het nie 'n positiewe voorstelling van 'koninkryk' gehad nie. Konings was op die boonste trappie van die maghebbers. In 'n 'koninkryk' ervaar kleinboere geweld - fisies en emosioneel. In God se koninkryk word die teendeel waar. Mense ervaar aanvaarding en heling na gees en liggaam. Vir Jesus is God se wêreld, oftewel die koninkryk van God, die gebied wat God se domein is, waar God se reëls geld wat gans anders is as menslike belange, wette en statusse.

Twee riglyne by die interpretasie van Jesus se gelykenisse help: (1) hoewel alledaagse beelde uit die gewone lewe van gemarginaliseerde mense gebruik word, keer hierdie beelde die lewe geheel om, sodat wanneer jy eenmaal in die verhaal in die gelykenis so ingetrek is dat jy selfs deel van die verhaal geword het, jou lewe nie meer dieselfde soos voorheen en soos gewoonlik kan wees nie; immers in God se koninkryk is alles anders as in die gewone lewe, insluitende jou politiek, jou finansies, jou status; (2) soek en vind die sin van die vergelyking. Hoe en hoekom word God se wêreld vergelyk met die gewone wêreld van mense?

Dikwels lê die antwoord opgesluit in die laaste woorde van die gelykenis, die sogenoemde 'das Gesetz der Achtergewichts' ('rule of end stress') (Linnemann ([1961] [1964] 1966:15; Snodgrass 2008:30). In hierdie verhaal vind jy dit in die laaste woorde in vers 13, naamlik 'jy kan nie tegelyk 'n slaaf van God wees én van die geldgod (Mammon) nie!' Om die 'raaisel' in hierdie vergelyking, oftewel 'analogie' (Snodgrass 2008:26-27) te verstaan, behoort ons te soek na die analogie tussen God se wêreld en die alledaagse wêreld van mense. Hierdie analogie is egter nie reglynig nie, maar kontrasterend (diafories) (vgl. Reinstorf \& Van Aarde 1998:603-622). Vir die antieke Mediterreense mense het status en eer (nasionale en familiale herkoms, koninklik, priesterlik, handelaar of ekonoom) geld en rykdom voorsien. Geld het nie status en eer gebring nie. Dit was andersom. Vir die heiden was die 'god van geld' (Mammon) aan jou kant omdat jy (of wanneer jy) reeds eer en status besit het. Jy is reeds slaaf van Mammon omdat jy oor ' $n$ bepaalde status en eer beskik het. Dit is onmoontlik vir 'n slaaf om nie haar of sy baas te dien nie. Bevryding is alleen moontlik deur werklik dood te gaan, en in Plato se sin te reinkarneer, of in Paulus se sin, uit die dood op te staan (vgl. Boers 2006:136, sodat 'We might walk in the newness of life'). 'n Slaaf is gebind aan haar of sy baas soos 'n slaaf aan kettings gebind is; soos om vasgemaak te wees aan jou 'kondisie' om Judeër, Hebreër en ras-eg te wees - dink aan Paulus se kategorieë in onder meer Filippense 3:4 e.v. en Romeine 11:1. Hierdie dinge was jou 'wins', jou 'belang' jou 'rykdom'. Om 'belangrik' te wees is om geld te besit. Jou status is jou wins. Dit wil sê, om 'belangrik' te wees is om 'eer' in die samelewing te besit; met ander woorde eer is nie dieselfde as eerbaarheid nie.

Dit is en was wel so dat slawe van Mammon ander mense kon 'koop' deur hulle slawe van jouself te maak omdat jy hulle militêr oorwin, seksueel verkrag, hulle eiendom onteien, hulle in skuld dompel, hulle van kleinboere tot huurwerkers verlaag, hulle vrouens en kinders as slawe verkoop omdat hulle jou nie kan terugbetaal nie.

En soos jy eenmaal slaaf van Mammon is op grond van jou menslike toestand - volgens Paulus, jou sarkikos-bestaan bly 'n mens lewenslank 'n slaaf as 'n baas jou gekoop het, jou vertrap, onderdruk, verkrag, jou vryheid en menslike waardigheid ontneem het. Net soos Lasarus, wat beteken 'God help', het 'n slaaf geen uitkoms as God nie betrokke raak nie. So was Lasarus die slaaf van die ryk koninklike; so het hy doodgegaan, lêende voor die toe deur van die man met die koninklike pers toga. Maar Lasarus kon wel tuis kom. Lasarus moes egter eers doodgaan. Hy kon nie tegelyk slaaf van Mammon én van God wees nie! Net God kan jou jou vryheid teruggee, sodat jy nie meer slaaf van óf Mammon óf van 'n ander mens hoef te wees nie.

Daar is klaarblyklik 'n rede dat Lukas hierdie eiendomlike gelykenisse in hoofstukke 15 en 16 een na die ander vertel: éérs die 'geldmorsende' (dieskorpisen - 15:13) jonger seun (Luk 15:11-32), dán die 'geldmorsende' (diaskorpizōn - 16:1) bestuurder (Luk 16:1-13), en laastens die 'doodganende' Lasarus (Luk 16:19-31). Twee elemente loop soos goue draad deur hierdie Die eiendomlike gelykenisse. Die eerste vind jy telkens aan die einde van die drie verhale waar jy hoor dat 'as jy sterf, jy weer lewe': ${ }^{25}$ In die eerste verhaal bly die oudste seun die slaaf van sy aardse erfporsie (tradisies) en het nie begrip vir die dansende 'goddelike patriarglose vader' wat die jonger seun wat dood was en weer lewe, in die 'goddelike huis van ewigheid' (koninkryk van God) terugontvang nie (kyk Luk 15:32).

In die derde verhaal vind jy die 'na-doodse' Lasarus wat saam met Abraham in die paradys tot lewe kom. Die koninklike met die pers toga het egter geen begrip vir die 'opgestane' iemand wat vanuit die dood aan hom die evangelie (= 'wet en profete') probeer verkondig nie (Luk 16:31). Daarom kan hy en sy soort nie die nodige kopskuif (metanoēsousin) maak nie (Luk 16:30).

25. Hierdie motief word ook by Paulus en Johannes aangetref. Dit is moontlik dat die Pauliniese teologie vir Lukas beïnvloed het (vgl. Walker 2009:9-14, veral wat ' $n$ sogenoemde 'Paulinisering' van Petrus in die Handelinge van die Apostels genoem word). 
Om die 'bestuurder' in die tweede verhaal 'wys' te noem is net so paradoksaal as om die Samaritaan 'goed' te noem! 'n Interpretasie wat by voorbaat die 'bestuurder' 'n 'skelm' noem (bv. Du Plessis 1990:1-20; vgl. Ireland 1992:7-14, 44), berus op die mislees van die kontras in die metafoor (= diafoor). Die bestuurder word deur Lukas inteendeel 'slim' of 'wys' genoem.

Waar die eerste element die kontras tussen doodgaan en nuwe lewe is (die eerste en die derde gelykenis), is die tweede element te vind in die Griekse woord diaskorpizō wat net twee keer deur Lukas gebruik word, te wete in Lukas 15:13 en in Lukas 16:1: in eersgenoemde 'vermors' die 'verlore seun' aardse goed (geld of besittings) en in laasgenoemde 'vermors' die bestuurder dit; in eersgenoemde verhaal was die seun verlore en is gevind (dood en lewe, soos in die derde verhaal, naamlik dié oor die 'arm Lasarus') en in laasgenoemde verhaal het dit met die bestuurder gebeur.

Onkonvensioneel het die 'dominee' ('bestuurder') se optrede meegebring dat die 'dominee' vriendskap ryker geword het. Hierdie vriendskap is nie maar soos die aardse goed wat bloot geërf is nie. Die vriendskap is die resultaat van 'n optrede soos dié van die storieverteller self, naamlik die Lukaanse Jesus (vgl. onder meer William Loader 1989:518-532). Daarom sê Jesus (Luk 16:9) dat hierdie vriendskap 'ewig' is en dit is 'n besitting vergelykbaar met 'ewige tente' (aiōnious skēnas) - nie soos 'n vaste tempel (of kerkgebou of kerk as instituut) met stene van vaste (primordiale of essensialistiese) tradisies gemaak nie, maar soos die tabernakel ('tente in die paradys', in 'God se koninkryk' - dit wil sê 'ewige tente') wat op en afgeslaan kan word omdat God se kinders vir 'veertig jaar' deur woestyne reis. In die Testament van Abraham (20.14), 'Abraham is reported as taken into paradise "where there are the tents of my righteous ones"' (in Snodgrass 2008:415)

Hoe sal die klein narratief van die pelgrimerende reisiger in Lukas 16:1-13 met 'n kulturele sensitiwiteit, teen die agtergrond van Michel Foucault se diskoers oor stryd teen die mag oorvertel kan word? Scott in Snodgrass (2008) antwoord soos volg:

By a powerful questioning and juxtaposition of images, the parable breaks the bond between power and justice. It equates justice and vulnerability and forces the hearer in the world of the kingdom to establish new coordinates for power, justice, and vulnerability. (p. 408)

Kom ons probeer nou met 'n oorvertelling!

'n Dominee (oikonomos) bestuur nie volgens tradisionele reëls die kerk (geloofgemeenskap van gewone mense) nie. Volgens Kloppenborg (1989:474-495) is dit die 'baas', en nie die 'bestuurder' nie, wat negatief uitgebeeld word. Daarom word die dominee tot verantwoording deur die heersende magte geroep, want die kerk gaan volgens die tradisionaliste ten gronde! Die dominee besef dat sy of hy geloofwaardigheid in die oё van die tradisionaliste verloor het en besluit om reglynig teen die gebruik 'vriendskap' by ander te soek.
Die 'tente van ewigheid' verwys na vriendskap by die kring buite die 'instituut van mag'. Die dominee (bestuurder) in die verhaal doen wat Jesus in sy modelgebed (Luk 11:3, 4) bid: 'Laat u koninkryk kom! Onthef ons van ons skuldlas soos ons die Ander se skuld vrystel!' Téén die belang van die maghebber in, verminder die dominee die skuld van skuldbeswaardes. Die dominee is lojaal aan die geringes en daarom is die dominee geloofwaardig in terme van wat volgens die wil van God die belangrikste is. Die dominee verleen waardigheid aan geringes deurdat sy of haar optrede dit moontlik maak dat mense hulle daaglikse lewe (brood) meer kan geniet; meer van die alledaagse lewe wat in sekere sin die 'onregverdige Mammon' is (v. 11): mense het meer van hulle dag se brood; meer olyfolie, meer brood (v. 6-8).

In die gelykenis is dit nooit duidelik wie in vers 8a die een is wat die dominee prys omdat die dominee (die bestuurder) so mildelik genade uitdeel deur te vergewe en nie verder te verswaar nie. Is dit Jesus wat prys? Is dit God? Is dit die belangrike baas van die bestuurder? Eksegete struikel in hulle soeke op 'n antwoord (vgl. Snodgrass 2008:412). Dit is egter 'n irrelevante vraag. Want die (diaforiese) analogie is duidelik. Die dominee word geprys want die dominee gebruik Mammon teen Mammon; die dominee is nie meer slaaf van die tradisie nie; die dominee verminder skuld; die dominee is anders as die man met die pers toga wat nie vir Lasarus brood wou gee nie; die dominee is die hand van God wat Lasarus in nood help; die dominee is soos die patriarglose pa wat, gans anders as die tradisionalistiese ouer broer, tradisie oorboord gooi en hardloop om die jonger 'geldmorsende' jonger 'sondaarkind' tuis te verwelkom.

Volgens Bailey (1976:86-118) wil die vergelyking (in vv. 1-8) sondaars oproep om volledig op God te vertrou en volgens Kloppenborg (1989:474-495; Snodgrass 2008:408): 'The parable celebrates the master's conversion from the myopia of ascribed honor.'

\section{Wat is die sin van die vergelyking?}

Volgens Derrett (1970:48-77; vgl Snodgrass 2008:407) gaan dit oor die 'right use of resources and the validity of God's standards'. Dit gaan oor vriendskap, oor lojaliteit, oor die evangelie, oor wat Jesus gedoen het, en oor wat ons behoort te doen. Dit gaan in ons hedendaagse konteks van konsumerisme oor koninkryksekonomie, oor digterstaal wat ryk is in beeld en ons lewens verryk op 'n manier wat geld nie kan doen nie. Dit gaan oor lojaliteit aan die evangelie. Dit gaan oor stryd teen mag. Snodgrass (2008:418) stel dit soos volg: 'Economic decisions are not easy, but the church should not only lead the way but demonstrate by its use of money the reality of its gospel.'

\section{Bevryding}

Om met die metafoor te eindig waarmee hierdie artikel begin: die vliegtuig het op die grond geland. Wat is die antwoord op die vraag oor mag? Hoe weerstaan ons mag? Met geweld? Sodat vrees - één van die drie groot magsdiskoerse volgens 
Steve Biko in terme van sý Suid-Afrika; die ander twee is liberalisme en apartheid - besweer kan word? Of behoort ons pelgrimsreis ooreenkoms met die lewensverhale van Steve Biko en Martin Luther King te vertoon? Wie is die pelgrim par excellence wat vir ons as Christene die eksemplaar van imitatio (vgl. onder meer Beck 1981:28-47) behoort te wees? In my antwoord kan ek maar net herhaal wat ek soveel keer reeds neergeskryf het - kyk veral my 'The cause of Jesus (Sache Jesu) as the canon behind the canon' (Van Aarde 2001:148-171).

Die resultaat van my eksegese van die verhale in Lukas 15 en 16 is dat 'ommekeer' (metanoia - vgl. Luk 5:32; 15:7) die sleutelmotief in Jesus se antwoord was op die geweld wat teenoor hom deur die heersende magte gepleeg is. Om Lukas se verhaal van die 'verlore seun' te lees as die lewensverhaal van 'n 'belydende Afrikaner', dié oor die sogenaamde 'skelm bestuurder' as die lewensverhaal van die 'bekeerde dominee' en dié oor die 'arm Lasarus' as die lewensverhaal van die 'barmhartige daklose', vra 'n kopskuif. ${ }^{26}$

En waar ek nog altyd my studente geleer het dat wanneer jy iemand in woorde móét navolg (siteer), dan doen jy dit nie omdat jy beweer jy kan dit nie beter as jou bron doen nie. Skryf eerder neer in jou eie woorde sodat jóú metanoia self lewende woorde word! Maar ek bieg! John Dominic Crossan (2007) het in sy boek God E Empire: Jesus against Rome, then and now, my oortuiging - reeds voorheen in my eie woorde neergepen - nou baie beter as ek self verwoord. Wat ek die Sache Jesu as die 'kanon agter die kanon' noem (Van Aarde 2001:148-171), beskou Crossan as dié kriterium vir bevryding van mag.

Dit sal ons myns insiens goed doen om ten slotte Crossan se woorde so volledig as moontlik te hoor, en dit kom deur mý parafrase.

Christene se Bybel verwoord 'n nimmer eindigende stryd. Dit is die stryd tussen, aan die een kant, die normaliteit van beskawing om patrone daar te stel om godsdiensoorloë te voer, sodat vrede deur onderdrukking gevestig kan word, en aan die ander kant, die radikaliteit van God se alternatief van hoe mense godsdienstig kan wees. En dit is deur nie-geweld en geregtigheid, sodat vrede gevind word in die doen wat reg is. Beide programme - vrede deur onderdrukking én vrede deur geregtigheid - word in die Bybel self aangetref.

Die feit dat beide visies Bybels is, verleen aan die Bybel integriteit en gesag. As die Bybel slegs vrede deur onderdrukking sou propageer, sal ons die Bybel nie nodig hê nie! As die Bybel se boodskap alléén oor vrede deur geregtigheid sou handel, sal ons dit nie geloofwaardig kon reken nie! Die menslike kondisie is dat ons gebind is om self tussen hierdie twee opsies te kies.

26. Dit is soos om oorreed te word dat ' $n$ Samaritaan as 'die barmhartige' in Lukas 10:25-37 gereken moet word (vgl. Bernard Brandon Scott 1989:189-202). In eietydse Westerse kultuur ken ons en aanvaar ons sulke paradokse. Lukas se gelykenis kan (op nie allegoriserende wyse) satiries gelees word as 'n 'grap' oor 'n 'Engelsman' (hoogheilige priester) en die 'Skot' (die 'minderwaardige' maar die 'hoër aangeskrewe' Leviet) en die 'Boer' (die goeie Samaritaan). Die antiek bedoelde leser sou die derde karakter as 'ék, die Israeliet' kon opneem, maa kokkend en verrassend vervang die veragtelike outsider die Israeliet as karakter Die sin van die vergelyking is dat laasgenoemde veronderstel word as dié ee wat die wet van God self beter ken as óf die priester óf die Leviet óf die 'gewone' Israeliet, en dit is naamlik om te weet hoe om die naaste te word vir hulle wat deu magsgebruik nobodies geword het.
As Christen het ek geen twyfel nie dat my keuse reeds deur die historiese Jesus, vir my, bepaal is. Dit is nie 'n gewelddadige God nie, maar die God van vrede deur niegeweld wat in en deur Jesus van Nasaret geopenbaar en aan ons verkondig is deur Paulus van Tarsus - en onthou dit is net Lukas wat Paulus só noem (kyk Hand 9:11; 21:39; 22:3).

Jesus is die norm van die Bybel, die kriterium hoe om die Nuwe Testament te interpreteer, die beliggaming van wat die evangelie is. Dit is die rede waarom ons, die Christene, 'n keuse tussen geweld en nie-geweld móét uitoefen. En die keuse? 'The person, not the book, and the life, not the text, are decisive and constitutive for us' (Crossan 2007:94-95).

\section{Literatuurverwysings}

Bailey, K.E., [1976] 1996, Poet \& peasant and through peasant eyes: A literary-cultural approach to the parables in Luke, combined edn., William B. Eerdmans Publishing Company, Grand Rapids, MI.

Beck, B.E., 1981, “Imitatio Christi" and the Lucan passion narrative', in W. Horbury $\&$ B. McNeil (eds.), Suffering and martyrdom in the New Testament, pp. 28-47, Cambridge University Press, Cambridge. http://dx.doi.org/10.1017/ CB09780511659591.004

Bentham, J., 1995, The pantopticon writings, ed. M. Bosovic, Verso, London.

Beukes, J., 2009, 'Hamartia: Foucault and Iran 1978-1979 (1: Introduction and texts)', HTS Teologiese Studies/Theological Studies 65(1), Art. \#124, 15 pages. http:// dx.doi.org/10.4102/hst.v.65i1.124

Beukes, J., 2011, 'Die konstellasie taalbegrip-logika in die Middeleeuse filosofie 1):Augustinustot Aquinas', HTS Teologiese Studies/Theological Studies 67(3), Art. \#1072, 15 pages. http://dx.doi.org/10.4102/hts.v67i3.1072

Biko, S., [1971] 2008, 'Some African cultural concepts', paper read at the Interdenominational Association of African Ministers (of Religion) Conference, Edenvale, in M. Setleoane, 2008, 'The development of black consciousness as a cultural and political movement (1967-2007)', in C.W. du Toit (ed.), 2008 , The legacy of Stephen Bantu Biko: Theological challenges, pp. 15-56, Research The legacy of Stephen Bantu Biko: Theological challenges, pp.
Institute for Theology and Religion, University of South Africa.

Biko, S., 1978, 'Black consciousness and the quest for a true humanity', in S. Biko (ed.) I write what I like, pp. 96-108, Macmillan, Johannesburg.

Boers, H., 2006, 'The meaning of Christ's resurrection in Paul', in J.H. Charlesworth et al. (eds.), Resurrection: The origin and future of a Biblical doctrine, pp. 104-137, Faith and Scholarship Colloquies, T\&T Clark, New York.

Böhm, M., 1999, Samarien und die Samaritai bei Lukas, Wissenschaftliche Untersuchungen zum Neuen Testament 2. Reihe, 111, Mohr Siebeck, Tübingen.

Bovon, F., 2005, Luke the theologian: Fifty-five years of research (1950-2005), Baylor University Press, Waco, TX.

Büchsel, F., 1985, s.v. 'allos' etc., in G.W. Bromiley (ed.), Theological Dictionary of the New Testament, ed. G. Kittel \& G. Friedrich, transl. G.W. Bromiley, p. 43 (TDNT I, pp. 264-267),William B. Eerdmans, Publishing Company, Grand Rapids, MI.

Crossan, J.D., 1995, Who killed Jesus? Exposing the roots of anti-Semitism in the Gospel story of the death of Jesus, Harper, San Francisco, CA.

Crossan, J.D., 2007, God and Empire: Jesus against Rome, then and now, HarperSanFrancisco, New York.

De Liagre Böhl, F.M.Th. \& Gemser, B., 1968, De psalmen: Tekst en uitleg, Uitgverij G.F. Callenbach N.V., Nijkerk.

Derrett, J.D.M., 1970, 'The parable of the unjust steward', in J.D.M. Derrett (ed.), Law in the New Testament, pp. 48-77, Darton, Longman \& Todd, London.

Dreyer, J.S. \& Pieterse, H.J.C., 2010, 'Religion in the public sphere: What can public theology learn from Habermas's latest work?', HTS Teologiese Studies/Theological Studies 66(1), Art. \# 798, 7 pages. http://dx.doi.org/10.4102/hts.v66i1.79

Dreyer, Y., 2002, 'Leadership in the world of the Bible: (De)institutionalization as an ongoing process', Verbum et Ecclesia 23(3), 625-641.

Du Plessis, I.J., 1990, 'Philanthropy or sarcasm? Another look at the parable of the dishonest manager', Neotestamentica 24, 1-20.

Du Plessis, I.J., 1995a, Die Evangelie volgens Lukas, Deel III: Griekse teks en aanduidings van die struktuur van die Evangelie, Lux Verbi, Kaapstad.

Du Plessis, I.J., 1995, Die Evangelie volgens Lukas, Deel II, Lux Verbi, Kaapstad.

Du Toit, C.W. (ed.), 2008, 'Black consciousness as an expression of radical responsibility: Biko an African Bonhoeffer', in The legacy of Stephen Bantu Biko: Theological challenges, pp. 199-207, Research Institute for Theology and Religion, University of South Africa.

English for Students, n.d., 'powers that be', viewed on 03 November 2011, from www. english-for-students.com/The-Powers.html

Esler, P.F., 2005, 'The Context Group Project: An autobiographical account', in L.J. Lawrence \& M.I. Aguilar (eds.), Anthropology \& biblical studies: Avenues of approach, pp. 46-61, Deo, Leiden.

Foucault, M., 1972, The archaeology of knowledge, transl. A. Sheridan, Tavistock, London.

Foucault, M., [1975] 1995, Discipline and punish: The birth of the prison, transl. A Sheridan, Vintage, New York. 
Foucault, M., 1977, Language, counter-memory, practice, transl. D.F. Bouchard \& S. Simon, Blackwell, Oxford.

Foucault, M., 1978, The history of sexuality, volume 1: An introduction, Vintage, New York.

Foucault, M., 1980, Power/knowledge, Harverster Press, Sussex.

Foucault, M., 1982, 'The subject and power', Critical Inquiry 8, 777-795. http://dx.doi org/10.1086/448181

Foucault, M., 1986, 'Disciplinary power and subjection', in S. Lukes (ed.), Power, pp. 229-242, Basil Blackwell, Oxford.

Gunneweg, H.J. \& Schmithals, W., [1980] 1982, Authority, transl. J.E. Steely, Abingdon, Nashville, TN. (Biblical Encounters Series.)

Habermas, J., 1971, Knowledge and human interests, Beacon, Boston, MA.

Habermas, J., 2001, Glauben und Wissen: Friedenspreis des Deutschen Buchhandels 2001, Suhrkamp, Frankfurt am Main.

Habermas, J., 2005, Zwischen Naturalismus and Religion: Philosophische Aufsätze Suhrkamp, Frankfurt am Main

Hedrick, C.W., 2004, Many things in parables: Jesus and his modern critics, Westmin Louisville, KY.

Holmberg ,1978,

Horsley, R.A., 2008, In the shadow of empire: Reclaiming the Bible as a history of faithful resistance, Westminster John Knox press, Louisville, KY.

Ireland, D.J., 1992, Stewardship \& the kingdom of God: An historical, exegetical \& contextual study of the parable of the unjust steward in Luke 16:1-13, Supplements to Novum Testamentum, vol. 70, E.J.Brill, Leiden.

Khoapa, B., 2008, 'African diaspora intellectual influences on Steve Biko', in C.W. du Toit (ed.), The legacy of Stephen Bantu Biko: Theological challenges, pp. 73-87, Research Institute for Theology and Religion, University of South Africa.

King, Martin Luther, [1958] 1986, 'Pilgrimage to nonviolence', in J.M. Washington (ed.), A testament of hope: The essential writings and speeches of Martin Luther King, pp. 35-40, HarperSanFrancisco, New York. (Oorspronklik gepubliseer in Stride toward freedom: The Montgomery story, Harper Row, New York, 1958.)

Kirk, A., 2005, 'The memory of violence and the death of Jesus in $Q$ ', in A. Kirk \& T. Thatcher (eds.), Memory, tradition, and text: Uses of the past in early Christianity, pp. 191-206, Society of Biblical Literature, Atlanta, GA. (SBL Semeia Studies 52.)

Kloppenborg, J.S., 1989, 'The dishonoured master (Luke 16,1-8a)', Biblia 70, 474-495.

Kloppenborg, J.S. \& Callon, C., 2010, 'The parable of the shepherd and the transformation of pastoral discourse', Early Christianity 1, 1-43.

Krämer, M., 1972, Das Rätzel der Parabel vom ungerechten Verwalter, Lk 16,1-13: Auslegungsgeschichte - Umfang - Sinn. Eine Diskussion der Probleme und Auslegungsgeschichte - Umfang - Sinn. Eine Diskussion der Probleme und
Lösungsvorschläge der Verwalterparabel von den Vätern bis heute, BibScRel, 5 PAS, Zürich.

Kroger, J., 1985, 'Prophetic-critical and practical-strategic tasks of the theology: Habermas and liberation theology', Theological Studies 46, 1-18.

Lang, S.B., 2004, 'The impact of video systems on architecture', PhD dissertation, Swiss Federal Institute of Technology.

Linnemann, E., [1961] [1964] 1966, Parables of Jesus: Introduction and exposition, transl. J. Sturdy, from the 3rd edn., 1964, SPCK, London.

Loader, J.A, 1975, 'Aspekte van menslike mag in die Ou Testament', ThD-proefskrif, Rijksuniversiteit Groningen.

Loader, W.R., 1989, Jesus and the rogue in Luke 16, 1-8a: The parable of the unjust steward', Revue Biblique, 518-532.

Lockhart, E., 2008, The disreputable history of Frankie Landau-Banks, Hyperion, New York. (An Imprint of Disney Book Group.)

McLean, S., 1996, 'Continuing education and the postmodern arts of power', Canadian Journal of University Continuing Education 22(2), 7-26.

Mommsen, W.J., 1992, The political and social theory of Max Weber: Collected essays, University of Chicago Press, Chicago, IL.

Moore, S.D., 1994, Poststructuralism and the New Testament: Derrida and Foucault a the Foot of the Cross, Fortress, Minneapolis, MN.

Moreschini, C. \& Norelli, E., 2005, Early Christian Greek and Latin literature: A literary history, Volume one: From Paul to the age of Constantine, transl. M.J. O'Connell, Hendrickson, Peabody, MA.

Nestle, E. \& Aland, K., 1964, Novum Testamentum Graeca et Latine, Editio vocesima secunda, Würtembergische Bibelanstalt, Stuttgart.

Newman, B.M. \& Nida, E.A., 1972, A translator's handbook on the Acts of the Apostles, vol. XII, United Bible Societies, London. (Help for Translators handbook.)

Niese, B., 1955, Flavii losephi opera, Weidman, Berlin.

Oakman, D.E., 1991, 'The countryside in Luke-Acts', in J.H. Neyrey (ed.), The social world of Luke-Acts: Models for interpretation, pp. 151-179, Hendrickson, Peabody, MA.

Ovidius, Metamorphoses (Met. lib. 15.), viewed 02 January 2011, from www. exclassics.com/anatomy/anatomy2.txt

Painchaud, L. \& Poirier, P.-H., 2006, Coptica-Gnostica-Manichaica: Mélanges offerts à Wolg-Peter Funk, Bibliothèque Copte Nag Hammadi, Peeters, Louvain.

Philo, I-X [1962], Volume X, Legatio ad Gaium, Loeb Classical Library, No. 379, ed. J.W. Earp \& transl. F.H. Colson, Harvard University Press, Cambridge, MA.

Phrase Dictionary - Meanings and Origins, viewed 02 January 2011, from www. phrases.org.uk

Pityana, N.B., 2008, 'Reflections on 30 years since the death of Steve Biko: A legacy revisited', in C.W. du Toit (ed.), The legacy of Stephen Bantu Biko: Theological challenges, pp. 1-14, Research Institute for Theology and Religion, University of South Africa.
Porter, S.E., 2006, 'Scripture justifies mission: The use of the Old Testament in LukeActs' in S.E. Porter (ed.), Hearing the Old Testament in the New Testament, pp. 104-126, William B. Eerdmans Publishing Company, Grand Rapids, MI.

Quintus Horatius Flaccus, [1823], Clevis Horatiana; or a key to the odes of Horace, to what is prefixed $A$ life of the poet and An account o the Horatian meters, G. and W.B. Whittaker, London.

Reinstorf, D. \& Van Aarde, A.G., 1998, 'Jesus' kingdom parables as metaphorical stories: A challenge to a conventional worldview', HTS Teologiese Studies/ Theological Studies 54(3/4), 603-622.

Rhoads, D. \& Michie, D., 1982, Mark as story: An introduction to the narrative of a Gospel, Fortress Press, Philadelphia, PA.

Robinson, W.C., 1960, 'The theological context for interpreting Luke's travel narrative (Lk 9:51ff.)', Journal of Biblical Literature 79, 2-31.

Schmidt, K.L., 1919, Rahmen der Geschichte: Literarkritische Untersuchung zur ältesten Jesusüberlieferung, Paternoster, Berlin.

Schmithals, W., 1980, Das Evangelium nach Lukas, Zürcher Bibelkommentare NT 3.1, Theologischer Verlag, Zürich.

Schmithals, W., 1987, 'Der Konflikt zwischen Kirche und Synagoge in Neutestamentlicher Zeit', in M. Oeming \& A. Graupner (Hrsg.), Altes Testament und christliche Verkündigung: Festschrift für Antonius H.J. Gunneweg zum 65. Geburtstag, pp. 366-386, Kohlhammer, Stuttgart.

Schmithals, W., 1994, Theologiegeschichte des Urchristentums: Eine problemgeschichtliche Darstellung, Kohlhammer, Stuttgart.

Seleoane, M., 'The development of black consciousness as a cultural and political movement (1967-2007)', in C.W. du Toit (ed.), The legacy of Stephen Bantu Biko: Theological challenges, pp. 15-56, Research Institute for Theology and Religion, University of South Africa.

Seland, T., 1995, Establishment violence in Philo \& Luke: A study of non-conformity to the Torah \& Jewish vigilante reactions, vol. 15, E.J. Brill, Leiden. (Biblical Interpretation Series)

Simpson, D.P., 1966, Cassel's new Latin-English English-Latin dictionary, 4th edn., Cassel \& Company, London.

Smith, A.H. \& O'Loughlin, J.L.N., sine anno, Odhams dictionary of the English language, Odhams Books Limited, Long Acre.

Snodgrass, K., 2008, Stories with intent: A comprehensive guide to the parables of Jesus, William B. Eerdmans, Grand Rapids, MI.

Stegemann, W., 1991, Zwischen Synagoge und Obrigkeit: Zur historischen Situation der lukanischen

Christen, Vandenhoeck \& Ruprecht, Göttingen. (FRLANT, 152.)

Stegemann, E.W. \& Stegemann, W. 1995, Urchristliche Sozialgeschichte: Die Anfänge im Judentum und die Christusgemeinden in der mediterranen Welt, Kohlhammer, Stuttgart.

Strelan, R., 2004, Strange Acts: Studies in the cultural world of the Acts of the Apostles, Beihefte zur Zeitgeschichte für die neutestamentliche Wissenschaft und die Künde der älteren Kirche, 126, Walter de Gruyter, Berlin.

The Phrase Finder, 'powers that be', viewed on 03 November 2011, from http://www. phrases.org.uk/meanings/the-powers-that-be.html.

Titus Livius, Ab Urbe Condita, viewed 02 January 2011, from www.en.wikipedia.org/ wiki/Livy

Van Aarde, A.G., 1986, 'The Wirkungsgeschichte of Matthew 28:16-20 in volkschristianisierende missiology' HTS Teologiese Studies/Theological Studies 42(1), 77-93. (Original printed in Afrikaans.)

Van Aarde, A.G., 1992, 'A S Geyser - lecturer in theology 1946-1961', HTS Teologiese Studies/Theological Studies 48(1/2), 159-182. (Original printed in Afrikaans.)

Van Aarde, A.G., 2001, 'The cause of Jesus (Sache Jesu) as the canon behind the canon', HTS Teologiese Studies/Theological Studies 57(1/2), 148-171.

Van Aarde, A.G., 2007, 'Sosiaal-wetenskaplike kritiese eksegese van NuweTestamentiese tekste - 'n voortgaande debat sonder einde', HTS Teologiese Studies/Theological Studies 63(3), 1120-1147.

Van Oort, J., 1991, Jerusalem and Babylon: A study into Augustine's City of God and the sources of his doctrine of the Two Cities, E.J. Brill, Leiden.

Van Oort, J., 2011, 'Augustinus' geschrift "De stad van God" (De civitate Dei): Een introductie tot de belangrijkste themata', HTS Theological Studies 67(1), Art. $\# 1017$, 9 pages. http://dx.doi.org/10.4102/hts.v67i1.1017

Van Tilborg, S. \& Chatelion Counet, P., 2000, Jesus appearances and disappearances in Luke 24, Brill, Leiden. (Biblical Interpretation Series.)

Walker, W.O., 2009, 'The "Paulinization" of Peter in the Book of Acts', The Fourth R 22(1), 9-14.

Wikimedia Foundation, 2010, 'Panopticon', modified on 26 December 2010, viewed 27 December 2010, from www.en.wikipedia.org/wiki/Panopticon

Wink, W., 1984, Naming the powers: The language of power in the New Testament, Fortress, Philadelphia, PA.

Wolter, M., 2008, Das Lukasevangelium, Handbuch zum Neuen Testament 5, Mohr Siebeck, Tübingen.

World Reference.com, n.d., 'powers that be', viewed, viewed 03 November 2010 from http://www.wordreference.com/es/translation.asp?tranword=powers\%20 from $h$ ttp://w

Zimmermann, R., 2008a, 'Gleichnisse als Medien der Jesuserinnerung: Die Historizität der Jesusparabeln im Horizont der Gedächtnisforschung', in R. Zimmermann (Hrsg.), Hermeneutik der Gleichnisse Jesu, unter Mitarbeit von G. Kern, pp. 87-121, Mohr Siebeck, Tübingen.

Zimmermann, R., 2008b, 'Im Spielraum des Verstehens: Chancen einer integrativen Gleichnishermeneutik', in R. Zimmermann (Hrsg.), Hermeneutik der Gleichnisse Jesu, unter Mitarbeit von G. Kern, pp. 3-24, Mohr Siebeck, Tübingen. 